NASA/TM-1999-208894

\title{
Surface Nuclear Power for Human Mars Missions
}

Lee S. Mason

Lewis Research Center, Cleveland, Ohio 
Since its founding, NASA has been dedicated to the advancement of aeronautics and space science. The NASA Scientific and Technical Information (STI) Program Office plays a key part in helping NASA maintain this important role.

The NASA STI Program Office is operated by Langley Research Center, the Lead Center for NASA's scientific and technical information. The NASA STI Program Office provides access to the NASA STI Database, the largest collection of aeronautical and space science STI in the world. The Program Office is also NASA's institutional mechanism for disseminating the results of its research and development activities. These results are published by NASA in the NASA STI Report Series, which includes the following report types:

- TECHNICAL PUBLICATION. Reports of completed research or a major significant phase of research that present the results of NASA programs and include extensive data or theoretical analysis. Includes compilations of significant scientific and technical data and information deemed to be of continuing reference value. NASA's counterpart of peerreviewed formal professional papers but has less stringent limitations on manuscript length and extent of graphic presentations.

- TECHNICAL MEMORANDUM. Scientific and technical findings that are preliminary or of specialized interest, e.g., quick release reports, working papers, and bibliographies that contain minimal annotation. Does not contain extensive analysis.

- CONTRACTOR REPORT. Scientific and technical findings by NASA-sponsored contractors and grantees.
- CONFERENCE PUBLICATION. Collected papers from scientific and technical conferences, symposia, seminars, or other meetings sponsored or cosponsored by NASA.

- SPECIAL PUBLICATION. Scientific, technical, or historical information from NASA programs, projects, and missions, often concerned with subjects having substantial public interest.

- TECHNICAL TRANSLATION. Englishlanguage translations of foreign scientific and technical material pertinent to NASA's mission.

Specialized services that complement the STI Program Office's diverse offerings include creating custom thesauri, building customized data bases, organizing and publishing research results ... even providing videos.

For more information about the NASA STI Program Office, see the following:

- Access the NASA STI Program Home Page at http://www.sti.nasa.gov

- E-mail your question via the Internet to help@sti.nasa.gov

- Fax your question to the NASA Access Help Desk at (301) 621-0134

- Telephone the NASA Access Help Desk at (301) 621-0390

- Write to:

NASA Access Help Desk

NASA Center for AeroSpace Information 7121 Standard Drive

Hanover, MD 21076 
NASA/TM-1999-208894

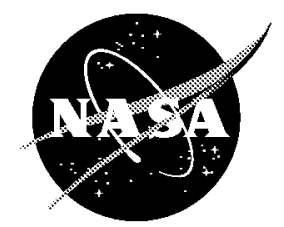

\section{Surface Nuclear Power for Human Mars Missions}

Lee S. Mason

Lewis Research Center, Cleveland, Ohio

Prepared for the

Space Technology and Applications International Forum cosponsored by the Boeing Company, Lockheed Martin, National Aeronautics and Space Administration, U.S. Air Force, and the U.S. Department of Energy Albuquerque, New Mexico, January 31-February 4, 1999

National Aeronautics and Space Administration

Lewis Research Center 
Available from

NASA Center for Aerospace Information 7121 Standard Drive

Hanover, MD 21076

Price Code: A03
National Technical Information Service 5285 Port Royal Road Springfield, VA 22100 Price Code: A03 


\title{
Surface Nuclear Power for Human Mars Missions
}

\author{
Lee S. Mason \\ NASA Lewis Research Center, Cleveland, OH 44135, (216) 977-7106 \\ Lee.Mason@lerc.nasa.gov
}

\begin{abstract}
The Design Reference Mission for NASA's human mission to Mars indicates the desire for in-situ propellant production and bio-regenerative life systems to ease Earth launch requirements. These operations, combined with crew habitation and science, result in surface power requirements approaching 160 kilowatts. The power system, delivered on an early cargo mission, must be deployed and operational prior to crew departure from Earth. The most mass efficient means of satisfying these requirements is through the use of nuclear power. Studies have been performed to identify a potential system concept using a mobile cart to transport the power system away from the Mars lander and provide adequate separation between the reactor and crew. The studies included an assessment of reactor and power conversion technology options, selection of system and component redundancy, determination of optimum separation distance, and system performance sensitivity to some key operating parameters. The resulting system satisfies the key mission requirements including autonomous deployment, high reliability, and cost effectiveness at a overall system mass of 12 tonnes and a stowed volume of about $63 \mathrm{~m}^{3}$.
\end{abstract}

\section{DESIGN REFERENCE MISSION}

The Design Reference Mission (DRM) consists of an initial unmanned cargo mission and three piloted missions to Mars over a period of seven years (Hoffman, 1997). Figure 1 shows the estimated power requirements through the seven-year buildup of the Mars surface base. A major premise of the DRM is that the initial cargo delivery includes an in-situ propellant production (ISPP) plant capable of producing the ascent propellant for the first piloted return mission. The complete ascent propellant needs of the first piloted return from Mars must be satisfied via the propellant plant before the crew departs Earth. The initial landed cargo delivery also includes a habitat module for the first crew and a life support system capable of producing a cache of water, oxygen, and buffer gases. The power requirements associated with this first cargo mission are expected to be about $50 \mathrm{~kW}: 25 \mathrm{~kW}$ for the propellant plant, $15 \mathrm{~kW}$ for the life support cache, and $10 \mathrm{~kW}$ for the habitat module. The power system must be operational shortly after arrival of the cargo to the surface to begin propellant and life support cache production and to maintain the habitat, long before the first humans arrive.

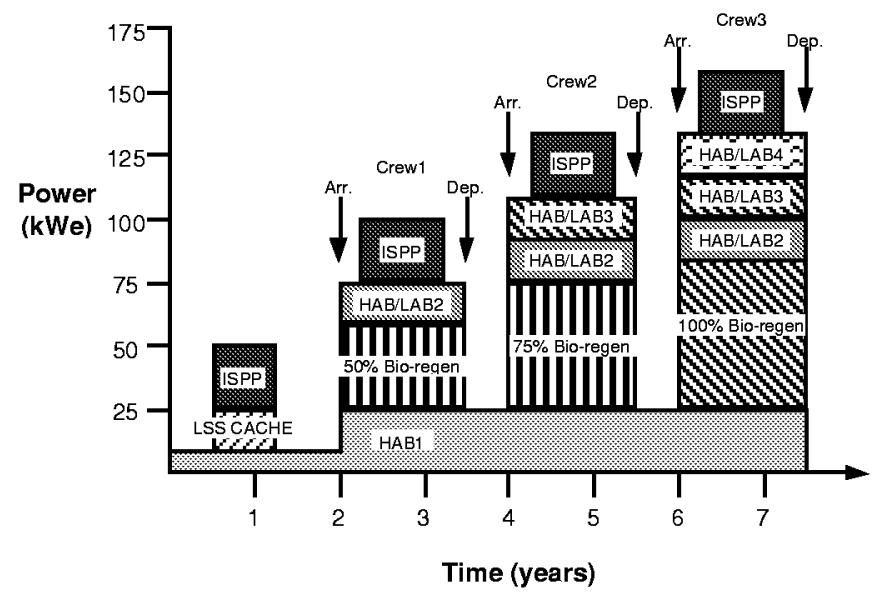

FIGURE 1. Mars Design Reference Mission Power Profile. 
With the arrival of the first crew, approximately 2 years after the earlier cargo arrival, power requirements increase to accommodate bio-regenerative life support systems. The first piloted mission also delivers a second habitat/laboratory module. Continued propellant production, combined with bio-regenerative life support and habitat requirements, result in an increase in the total power requirements to about $100 \mathrm{~kW}$. The surface mission for the first crew is expected to be about 18 months.

The second and third piloted missions each deliver an additional habitat/laboratory module. The bio-regenerative life support systems undergo increasing levels of closure with each mission, reducing the reliance on Earth-borne logistics re-supply. Upon arrival of the third crew, six years after the initial cargo delivery mission, the total power requirements of the Mars base are about $160 \mathrm{~kW}$.

\section{POWER SYSTEM OPTIONS}

There are several options to satisfy the DRM power profile. Smaller, incremental power systems could be delivered with each mission, on an as-needed basis. The power system for the initial cargo mission would be sized for $50 \mathrm{~kW}$. The first piloted mission would deliver an additional $50 \mathrm{~kW}$ system, followed by $30 \mathrm{~kW}$ systems on each of the subsequent piloted missions. This approach was dismissed due to limited payload capacity on the piloted missions. Instead, a single $160 \mathrm{~kW}$ power plant was presumed for the initial cargo mission. A second $160 \mathrm{~kW}$ system was manifested for the first piloted mission to provide $100 \%$ power redundancy. This approach offers the benefit of increased payload capability for the latter piloted missions, assured crew safety through power system redundancy and the advantage of economy of scale afforded by the larger system. An additional $10 \mathrm{~kW}$ auxiliary power unit was added to the manifest to provide emergency back-up and to serve as a power supply for crew rovers and remote science equipment. A 10 year power system life was assumed to assure long term operation beyond the DRM.

Both solar and nuclear power technologies were considered for the $160 \mathrm{~kW}$ power plant. A solar power system using non-tracking photovoltaic arrays and regenerative fuel cells for nighttime power is estimated to weigh about 60 tonnes and have a stowed volume of about $1500 \mathrm{~m}^{3}$ (Hoffman, 1997). The DRM Mars cargo lander, capable of delivering a maximum of 65 tonnes and $625 \mathrm{~m}^{3}$ to the surface, would be undersized for the solar power system. Alternatively, a $160 \mathrm{~kW}$ nuclear power system, with Earth-delivered shielding, weighs less than 15 tonnes and has a stowed volume of about $65 \mathrm{~m}^{3}$.

\section{Nuclear Power System Concept}

The key requirements for the $160 \mathrm{~kW}$ nuclear power plant include autonomous deployment, high reliability, and low cost. The autonomous deployment requirement is derived from the fact that system must be operational for the propellant production plant and life support systems prior to crew arrival. High reliability is necessary to assure crew safety. Low cost is essential if the overall mission is to be accepted by NASA Headquarters, Congress, and the American public.

Autonomous deployment and crew radiation safety were mutually satisfied through the concept of a mobile deployment cart. The reactor power system, mounted on a wheeled cart, is lowered to the surface and telerobotically driven to a safe distance from the habitat prior to system startup. This minimizes the amount of manrated shielding required for the reactor. Options to reduce this shield mass by using indigenous shielding or site topography might also be considered. As the cart drives from the landing site, a pre-attached power transmission cable is unfurled from a cable spool located on the cart body. Once in place, telemetry signals from Earth would command the system to deploy waste heat radiator panels, withdraw reactor control rods, and begin electrical power generation. The electrical power to propel the cart and deploy the power system is provided by the $10 \mathrm{~kW}$ auxiliary power unit, and the mass of the deployment cart was assumed to be $15 \%$ of the total power system mass. Analysis to determine the optimum separation distance of the cart relative to the crew habitat area is presented later in this paper.

System cost was presumed to be a critical design factor. The key system drivers that effect system cost are the reactor heat source technology and the power conversion technology. Options for the nuclear heat source include liquid-metal cooled reactors (LMCR), such as SP-100, or gas cooled reactors (GCR). The LMCR option has the advantage of design heritage from the work completed during the recent SP-100 program, including fuel and materials development, and system design optimization. The GCR option offers the potential for common reactor technology with the baseline nuclear thermal transportation system. Analysis of both options to assess the overall system performance impacts can be found in the system analysis section. 
Options for power conversion include dynamic systems: Brayton, Stirling, and Rankine, and static systems: Thermoelectric, Thermionic, and AMTEC (Alkali-metal Thermal-to-Electric Converter). System cost is most influenced by performance, weight and technical readiness. Both free-piston Stirling and liquid-metal Rankine conversion offer excellent performance potential, but lack a commercial infrastructure for development of spacerated engines in this power regime. Thermoelectric technology lacks an on-going development program and has relatively low performance potential. Thermionic, either in-core or out-of-core, and AMTEC technology both have excellent performance potential but may lack technical maturity, especially at this power level. Brayton conversion was selected for this study based on the combination of high performance, low weight potential and demonstrated technology readiness. An added benefit with Brayton conversion is the potential to eliminate the reactor primary heat exchanger when combined with a GCR. Analysis to determine performance sensitivity to peak cycle temperature and recuperator effectiveness is provided in the system analysis section of this paper.

High reliability was addressed in an overall context by having a completely redundant power system delivered on the first piloted mission. In addition, redundancy was planned for the power conversion, waste heat rejection, and power management and distribution (PMAD) subsystems. After comparing several options, an engine configuration with " $3 / 2$ " redundancy was selected to assure reliable operation without significant impact to system mass. The " $3 / 2$ " configuration includes 3 engines with 2 needed for full power operation, resulting in an engine rating of 80 $\mathrm{kW}(160 \div 2)$ and a normal operating level of $53.5 \mathrm{~kW}(160 \div 3)$. As a design guideline, it was assumed that each engine would have its own dedicated radiator capable of full power heat rejection. An alternative would be to have a common radiator shared among the three engines. The " $3 / 2$ " engine and dedicated radiator configuration provides $150 \%$ design capacity, and allows up to 1 module failure without effecting power output. The PMAD subsystem, including converters and transmission cabling, was selected to have "4/3" (133\% design capacity) redundancy meaning that four independent channels are available, with three channels needed for full power.

\section{SYSTEM ANALYSIS RESULTS}

The key analytical studies identified during the concept development were as follows: 1) determination of optimum reactor separation distance, 2) comparison of LMCR and GCR reactors, and 3) system mass sensitivity associated with peak cycle temperature and recuperator effectiveness variations.

In all studies, the Brayton cycle efficiency was optimized for minimum system mass. This optimization represents a trade-off of heat source mass (reactor and shield) versus radiator mass. Higher efficiency results in a smaller heat source, but lower heat rejection temperature leading to a larger radiator. Lower efficiency yields a high heat rejection temperature to reduce radiator size at the expense of a more massive heat source.

\section{Optimum Separation Distance}

The trade-off of reactor shield mass and transmission cable mass yields an optimum separation distance for the reactor power system. A man-rated shielding concept, shown in Figure 2, was developed for this analysis. The shielding consists of alternating layers of lithium-hydride $(\mathrm{LiH})$ and tungsten $(\mathrm{W})$, in a cylindrical configuration, to provide neutron and gamma radiation attenuation $360^{\circ}$ surrounding the reactor core. A thicker segment was assumed to provide increased attenuation in the direction of the crew base of operations. Instrument rated shields on the top and bottom were included to minimize radiation scatter. Using OSHA standards as a basis, dose rates were chosen to be less than $5 \mathrm{rem} / \mathrm{year}$ in the direction of the crew base and less than $50 \mathrm{rem} / \mathrm{year}$ outside the crew inclusion zone. The crew inclusion zone was conservatively chosen to be $90^{\circ}$. In order to assure a reasonable transmission cable mass with the large separation distance, cable voltage was assumed to be 5000 volts. The cable was further assumed to be bare aluminum conductors laid on the surface with the conductor diameter sized to maintain safe operating temperature.

Figure 3 shows the variation in system mass as a function of separation distance for a gas-cooled reactor power system with a $1300 \mathrm{~K}, 95 \%$ recuperated Brayton conversion system. The mass includes the reactor, shield, power conversion, PMAD, and deployment cart. As expected, shield mass dominates at shorter distances while PMAD mass is minor. At the larger separation distances, PMAD mass becomes a significant percentage of the overall system. The optimum separation distance is $2.8 \mathrm{~km}$ which relates to a system mass of about 12 tonnes. 


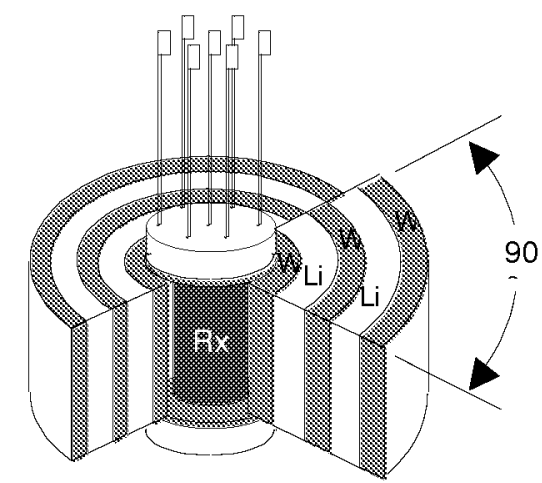

FIGURE 2. Man-rated Shielding Concept.

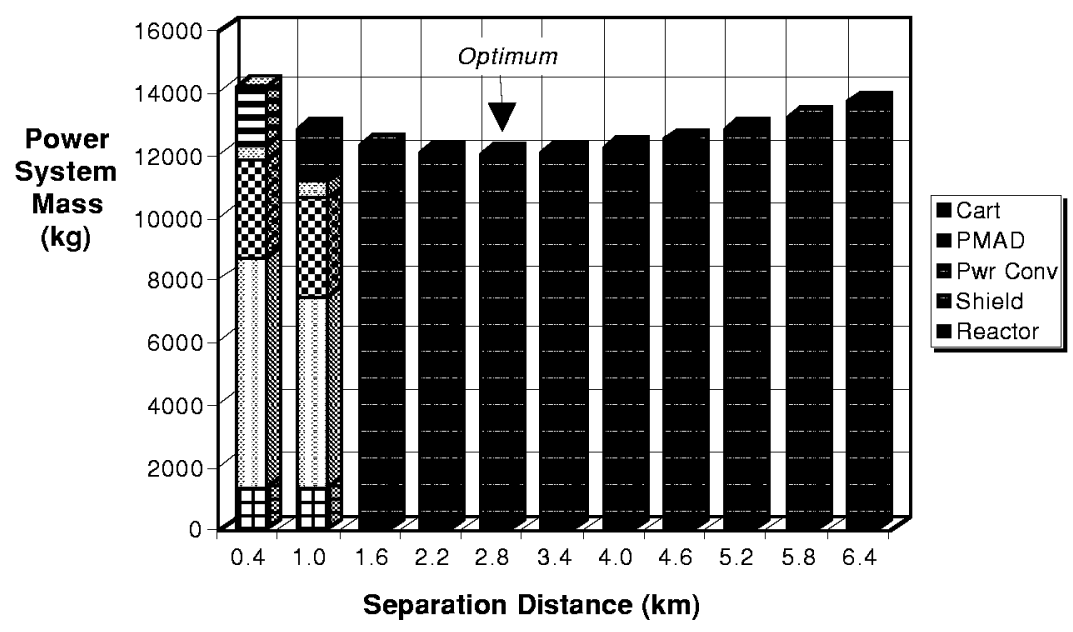

FIGURE 3. Shield Mass versus PMAD Optimum Separation Distance.

\section{Reactor Comparison}

The LMCR concept in this study is based on SP-100 and sized using Sandia National Laboratory's RSMASS computer model (Marshall, 1991). The reactor mass was calculated based on the thermal power requirement of the power conversion system and includes a liquid-to-gas, primary heat exchanger. The reference GCR concept was based on Pratt and Witney's Escort design (Joyner, 1999). Escort was conceived to provide a common reactor technology for surface power and nuclear thermal propulsion. The reactor weighs $1302 \mathrm{~kg}$, and in surface power mode can provide up to $750 \mathrm{kWt}$ for 10 years. In performing the system analyses, the Escort mass was held constant, with thermal power limited to the $750 \mathrm{kWt}$ maximum. The man-rated shielding mass, a function of reactor thermal power and the radiation dose constraints, was determined using a simplified algorithm developed at Lewis, based on previous Monte-Carlo neutron calculations.

The performance characteristics of the two reactor power system concepts are presented in Table 1. The smaller core diameter and length of the LMCR results in a considerable shield mass savings. The reduced reactor core and shield mass contributes to a decrease in the optimum separation distance and a slightly higher optimized cycle efficiency. The latter result effects a minor increase in radiator area $\left(310 \mathrm{~m}^{2}\right)$ relative to the GCR system $\left(285 \mathrm{~m}^{2}\right)$. Overall, the LMCR system provides a $11 \%$ mass savings over the GCR power system. In the context of the overall cart dimensions, the system stowed volume for the two systems was the same at about $63 \mathrm{~m}^{3}$. Missing from this comparison is the benefit of having a single reactor satisfy both power and propulsion requirements. Qualitatively, the potential mission cost savings would appear to outweigh the modest mass penalty of the GCR system. 
TABLE 1. Comparison of $160 \mathrm{~kW}$ Liquid-Metal Cooled and Gas Cooled Reactor Power Systems.

\begin{tabular}{|l|c|c|}
\hline & GCR & LMCR \\
\hline Heritage & Escort & SP-100 \\
Thermal Power (kWt) & 716 & 659 \\
Reactor OD (cm) & 67.5 & 56.7 \\
Reactor Length (cm) & 81.0 & 53.8 \\
Optimum Separation (km) & 2.8 & 2.4 \\
\hline Reactor (kg) & 1302 & 1428 \\
Shield (kg) & 4875 & 3622 \\
Power Conversion (kg) & 3134 & 3259 \\
PMAD (kg) & 1131 & 963 \\
Cart (kg) & 1566 & 1391 \\
\hline Total (kg) & 12009 & 10663 \\
\hline
\end{tabular}

\section{Brayton Performance Sensitivities}

Two of the major performance drivers for the Brayton system are recuperator effectiveness and peak cycle temperature. Recuperator effectiveness (Er) determines the amount of heat extracted from the turbine discharge to pre-heat the supply gas to the reactor. Higher effectiveness values result in higher cycle efficiency and reduced radiator area. The drawback to high recuperator effectiveness is the weight of the heat exchanger, which becomes more massive with increasing effectiveness. In reactor power system trade studies, the Brayton system is usually either non-recuperated $(\mathrm{Er}=0)$ or highly recuperated $(\mathrm{Er}=95 \%)$.

Peak cycle temperature, or more specifically turbine inlet temperature, has an even more pronounced effect on system performance. Higher temperatures allow the Brayton unit to operate at increased efficiency while maintaining a high heat rejection temperature for reduced radiator size. However, the high temperature operation requires more exotic material choices to assure sufficient operating life without creep fatigue (Juhasz, 1993). Stateof-the-art Brayton systems operate at about $1100 \mathrm{~K}$ using nickel-based superalloys for all high temperature components. The next generation of Brayton engines will likely use refractory alloys to achieve peak operating temperatures of $1300 \mathrm{~K}$. Ceramic and high temperature composite materials would be required to achieve peak cycle temperatures above $1500 \mathrm{~K}$.

Figure 4 presents the performance sensitivities associated with recuperator effectiveness and turbine inlet temperature (TIT). The chart examines GCR power system mass versus total radiator area for a series of massoptimized design points. Radiator area is considered an important performance parameter since it is strongly related to the system stowed volume. Considering the $95 \%$ recuperated cases, a $1000 \mathrm{~kg}(8 \%)$ mass savings and a $250 \mathrm{~m}^{2}$ (48\%) area savings is realized by increasing the turbine inlet temperature from $1100 \mathrm{~K}$ to $1300 \mathrm{~K}$. The performance gains associated with a temperature increase to $1500 \mathrm{~K}$ are reduced to $500 \mathrm{~kg}(4 \%)$ and $90 \mathrm{~m}^{2}(32 \%)$, relative to the $1300 \mathrm{~K}$ design point. Comparing non-recuperated to highly recuperated performance at $1300 \mathrm{~K}$, there is a relatively minor $275 \mathrm{~kg}(2 \%)$ mass penalty and a substantial $115 \mathrm{~m}^{2}(30 \%)$ area savings with the $95 \%$ recuperated system. An interesting result is the slope of the lines connecting the non-recuperated and $95 \%$ recuperated cases for each of the three temperatures. The change in slope is based on the effective rejection temperature and the percent of radiator mass to overall system mass. At $1100 \mathrm{~K}$ where radiator mass accounts for a major portion of the system mass, recuperation is preferred in order to minimize the radiator. Conversely, the non-recuperated case appears to be the preferred option at $1500 \mathrm{~K}$, based on the minimal impact of recuperation on radiator area. Overall, the recommended design point is $1300 \mathrm{~K}$ with a $95 \%$ recuperator based on "reasonable" mass and area performance, using relatively near term materials technology. 


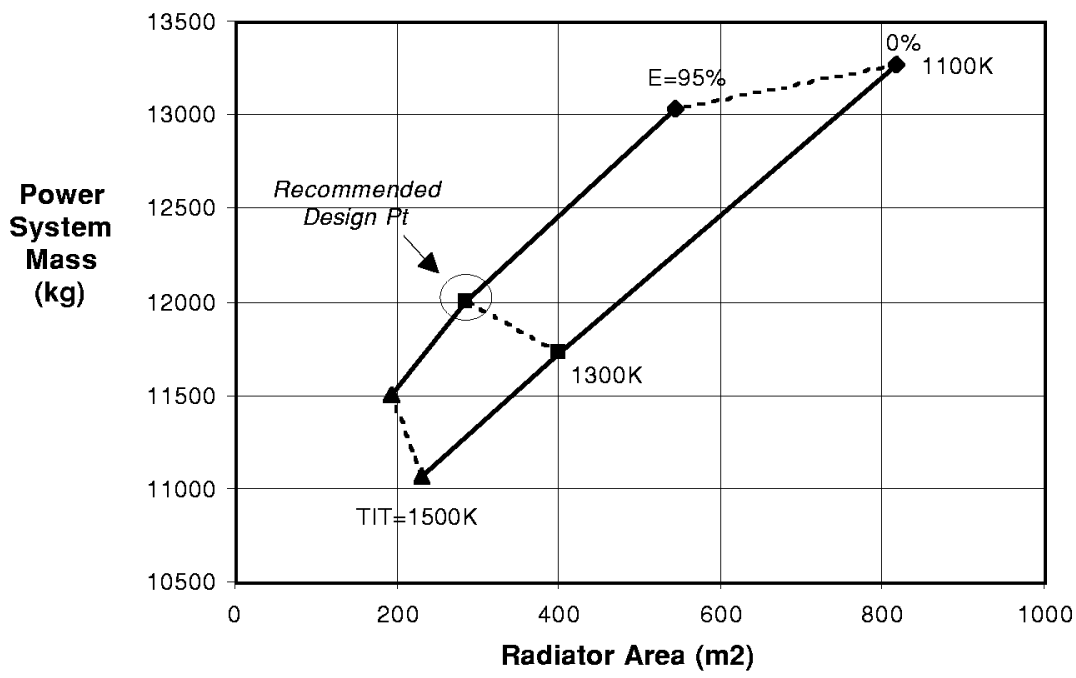

FIGURE 4. GCR-Brayton Performance Sensitivities.

\section{SUMMARY}

The high power and autonomous deployment requirements of NASA's Mars Design Reference Mission are well suited to the use of nuclear surface power. The concept presented in this paper offers low mass and stowed volume as well as high reliability and safety. A mobile cart is used to transport the reactor power system to a safe distance from the habitat area prior to startup. Comparison of reactor and power conversion options indicate that a GCRBrayton system provides high performance while maintaining commonality with the nuclear thermal propulsion system. System optimization and parametric sensitivity studies provided the means to select the preferred concept design characteristics. The resulting design point weighs about 12 tonnes with a deployed radiator area of $285 \mathrm{~m}^{2}$ and a stowed volume of $63 \mathrm{~m}^{3}$.

\section{REFERENCES}

Hoffman, S.J., and Kaplan, D.I., editors, "Human Exploration of Mars: The Reference Mission of the NASA Mars Exploration Study Team," NASA Special Publication 6170, July 1997.

Joyner, R., and Feller, G.J., "Manned Mars Mission Enhancements Using Pratt \& Whitney Escort Combined Propulsion And Power System," Proceedings of the Space Technology and Applications International Forum (STAIF-99), 1999.

Juhasz, A.J., El-Genk, M.S., and Harper, W.B., "Closed Brayton Cycle Power System with a High Temperature Pellet Bed Reactor Heat Source for NEP Applications," $10^{\text {th }}$ Symposium on Space Nuclear Power and Propulsion Proceedings, 1993.

Marshall, A.C., and Gallup, D.R., "RSMASS-D: Reactor and Shield Mass Minimization Models," $8^{\text {th }}$ Symposium on Space Nuclear Power Systems Proceedings, 1991. 
\begin{tabular}{|l|c|c|}
\hline 1. AGENCY USE ONLY (Leave blank) & $\begin{array}{c}\text { 2. REPORT DATE } \\
\text { January } 1999\end{array}$ & $\begin{array}{r}\text { 3. REPORT TYPE AND DATES COVERED } \\
\text { Technical Memorandum }\end{array}$
\end{tabular}

\section{TITLE AND SUBTITLE}

Surface Nuclear Power for Human Mars Missions

\section{FUNDING NUMBERS}

$$
\text { WU-632-1A-10-00 }
$$

Lee S. Mason

\section{PERFORMING ORGANIZATION NAME(S) AND ADDRESS(ES)}

National Aeronautics and Space Administration

Lewis Research Center

Cleveland, Ohio 44135-3191
8. PERFORMING ORGANIZATION REPORT NUMBER

E-11485

\section{SPONSORING/MONITORING AGENCY NAME(S) AND ADDRESS(ES)}

National Aeronautics and Space Administration

Washington, DC 20546-0001

10. SPONSORING/MONITORING AGENCY REPORT NUMBER

NASA TM-1999-208894

\section{SUPPLEMENTARY NOTES}

Prepared for the Space Technology and Applications International Forum cosponsored by the Boeing Company, Lockheed Martin, National Aeronautics and Space Administration, U.S. Air Force, and the U.S. Department of Energy, Albuquerque, New Mexico, January 31-February 4, 1999. Responsible person, Lee S. Mason, organization code 5490, (216) 433-7106.

Unclassified - Unlimited

Subject Categories: 20 and 91

Distribution: Nonstandard

This publication is available from the NASA Center for AeroSpace Information, (301) 621-0390.

\section{ABSTRACT (Maximum 200 words)}

The Design Reference Mission for NASA's human mission to Mars indicates the desire for in-situ propellant production and bio-regenerative life systems to ease Earth launch requirements. These operations, combined with crew habitation and science, result in surface power requirements approaching 160 kilowatts. The power system, delivered on an early cargo mission, must be deployed and operational prior to crew departure from Earth. The most mass efficient means of satisfying these requirements is through the use of nuclear power. Studies have been performed to identify a potential system concept using a mobile cart to transport the power system away from the Mars lander and provide adequate separation between the reactor and crew. The studies included an assessment of reactor and power conversion technology options, selection of system and component redundancy, determination of optimum separation distance, and system performance sensitivity to some key operating parameters. The resulting system satisfies the key mission requirements including autonomous deployment, high reliability, and cost effectiveness at a overall system mass of 12 tonnes and a stowed volume of about $63 \mathrm{~m}^{3}$.

\section{SUBJECT TERMS}

Nuclear electric power generation; Mars surface; Brayton cycle
15. NUMBER OF PAGES

12

16. PRICE CODE

$\mathrm{A} 03$

20. LIMITATION OF ABSTRACT

\begin{tabular}{l|c|c|}
$\begin{array}{l}\text { 17. SECURITY CLASSIFICATION } \\
\text { OF REPORT } \\
\text { Unclassified }\end{array}$ & $\begin{array}{c}\text { 18. SECURITY CLASSIFICATION } \\
\text { OF THIS PAGE } \\
\text { Unclassified }\end{array}$ & $\begin{array}{c}\text { 19. SECURITY CLASSIFICATION } \\
\text { OF ABSTRACT } \\
\text { Unclassified }\end{array}$
\end{tabular}

Standard Form 298 (Rev. 2-89)

Prescribed by ANSI Std. Z39-18 298-102 